\title{
Student Motivation in Learning Chukyuu Kaiwa II Through the Application of Blended Learning Method
}

\author{
Rahtu Nila Sepni ${ }^{1}$, Radhia Elita ${ }^{2}$ \\ \{rahtunilasepni@hum.unand.ac.id ${ }^{1}$, radhiaelita@hum.unand.ac.id $\left.{ }^{2}\right\}$ \\ 1,2 Japanese Literature, Universitas Andalas, Padang, Indonesia
}

\begin{abstract}
This research tries to find out the motivation level of the student when learning Chukyuu Kaiwa II with the blended learning method. Questionnaire method is applied in collecting the data, it is then found out that students don't have high motivation to learn Chukyuu Kaiwa. From the overall answered questionnaire only $30 \%$ of the students who answer "highly motivated", while $24 \%$ answered that they "don't really have an interest" in the subject, $29 \%$ replied with "doubt" and 17\%" answered with "no interest"
\end{abstract}

Keywords: motivation, method, learning, blended learning.

\section{Introduction}

Chukyuu Kaiwa II is a subject that is given to university students who are in their VI semester in Japanese Department with 2 credits included on the subject. Chukyuu Kaiwa II requires students to master the entire aspects of language use including; listening, speaking, reading and writing that correspond to their level of proficiency. Words and sentences that should be mastered by students are quite complex since they are not limited to daily words and conversation, it also includes words that are common in the working environment. The purpose of this subject is to train the students to be fluent during their job hunting interviews as well as to exercise their speaking capability which is crucial for their working skill.

Not only does the subject is presented in the lecture class base, but it also requires some forms of assessments that should be completed by the students. In consequence, the lecturer must give an evaluation of all aspects of language that are previously mentioned. In the previous years, Chukyuu Kaiwa II subject on Faculty of Humanities Andalas University had only been evaluated trough group assessments. The groups that completed the task earlier would do the role-play in front of the class to get an additional mark, while those who couldn't complete the task would not have a chance to present their task dues to time limitation. Evaluation matrix that had been used to mark the student on Chukyuu Kaiwa II subject can be seen on the following chart: 
Tabel 1: marking matrix on the previous semester

\begin{tabular}{|c|c|c|c|}
\hline \multirow{2}{*}{$\begin{array}{l}\text { Mark } \\
\text { in } \\
\text { Letter }\end{array}$} & \multirow{2}{*}{ Range } & \multicolumn{2}{|c|}{ Mastered Capabilities } \\
\hline & & Hard skills & Soft skills \\
\hline A & $91-100$ & $\begin{array}{l}\text { Level } 3 \text { toward } 2 \text { on words mastery } \\
\text { The conversation relates to the } \\
\text { given theme } \\
\text { The used of sentence structures are } \\
\text { suitable with the language structure } \\
\text { and context. }\end{array}$ & $\begin{array}{l}\text { Loud voice } \\
\text { Fluent speaking } \\
\text { Clear pronounciation } \\
\text { Correct intonation }\end{array}$ \\
\hline A- & $81-90$ & $\begin{array}{l}\text { Level } 3 \text { or lower in words mastery } \\
\text { The conversation is less consistent } \\
\text { with the theme } \\
\text { The sentence structures are not } \\
\text { appropriate with the proper } \\
\text { language structure and context. }\end{array}$ & $\begin{array}{l}\text { Not loud enough when speaking } \\
\text { Not fluent } \\
\text { The pronunciation is not clear } \\
\text { The intonation is not precise }\end{array}$ \\
\hline $\mathrm{B}+$ & $71-80$ & $\begin{array}{l}\text { Level } 4 \text { in words mastery } \\
\text { The conversation is out of the given } \\
\text { theme } \\
\text { The words and sentence structure } \\
\text { are not suitable for the current } \\
\text { language structure and context }\end{array}$ & $\begin{array}{l}\text { Speak softly } \\
\text { Not fluent in speaking, did not } \\
\text { memorize the line, or see the note } \\
\text { while presenting the role play } \\
\text { Unclear pronunciation } \\
\text { Incorrect intonation }\end{array}$ \\
\hline B & $61-70$ & Present during the class but do not tal & part in role-playing \\
\hline B- & $51-60$ & $\begin{array}{l}\text { Do not present on the class with an a } \\
\text { to the lecturer then the students will } r \\
\text { and marks }\end{array}$ & $\begin{array}{l}\text { ceptable excuse, if the students report } \\
\text { eive the opportunity to get evaluation }\end{array}$ \\
\hline $\mathrm{C}$ & $40-50$ & Do not present in the class and give $n$ & explanation \\
\hline
\end{tabular}

The matrix indicates that students who cannot complete the given task in front of the class will be marked around B. the previous record shows that students who present their task in front of the class are the same students, while the rest of the students position themselves as students who potentially get B for the subject. This group of students needs motivation and force to show their capability in performing their task in front of the class. The previous semester marks on students who take the subject are seen as follow:

Table 2: Student Mark and Mid Term Test on the previous year

CHUKYUU KAIWA II A

EVEN SEMESTER 2017/2018

\begin{tabular}{|c|c|c|c|c|c|c|c|c|}
\hline \multirow[b]{2}{*}{ No } & \multirow[b]{2}{*}{$\begin{array}{l}\text { Student } \\
\text { Number }\end{array}$} & \multirow[b]{2}{*}{ Student Name } & \multicolumn{5}{|c|}{ Assessment $40 \%$} & \multirow{2}{*}{$\begin{array}{l}30 \% \\
\text { Mid } \\
\text { Test }\end{array}$} \\
\hline & & & AsI & $\begin{array}{c}\text { As } \\
\text { II }\end{array}$ & AsIII & Pres. & $\begin{array}{l}\text { Ass. } \\
\text { Avrg }\end{array}$ & \\
\hline 1 & 1310752001 & $\begin{array}{l}\text { DICKY MALTA } \\
\text { ALBUQORI }\end{array}$ & 65 & 70 & 70 & 60 & 66 & 12 \\
\hline 2 & 1410755001 & RIRI FITRIANI & 87 & 88 & 81 & 100 & 89 & 100 \\
\hline 3 & 1510751001 & IFTIKHARI R AMIENI & 87 & 80 & 81 & 80 & 82 & 100 \\
\hline 4 & 1510751003 & MELDA VIANA & 65 & 70 & 81 & 70 & 72 & 16 \\
\hline 5 & 1510751005 & NURSYA EKA PUTRI & 80 & 70 & 83 & 60 & 73 & 96 \\
\hline 6 & 1510751009 & $\begin{array}{l}\text { MASYITHA PUTRI } \\
\text { IMANA }\end{array}$ & 80 & 70 & 81 & 70 & 75 & 44 \\
\hline Etc & $\ldots$. & & & & & & & \\
\hline
\end{tabular}


The table of the student mark indicates that only a few students who got A (85-100); from the total of 30 students, only 5 of them who got higher than 85 which means that only $17 \%$ students who got A for the subject. Those marks had been recorded since the first meeting on class, as the students had mastered the materials and actively participate in class on the first meeting. The table also indicates the distribution of students who got A is only for those who follow the learning process actively because the final mark is calculated from $40 \%$ of the process.

Trough the evaluation and marking the students, some problems occur during the process; they mostly relate to the limited time that is given to the student in order to complete the equitable assessment. A possible solution to answer this problem is the application of $i$ learning model in which the evaluation aspects toward the student are possible trough quizzes, conversation, and others. These features will mitigate any problem that hinders the lecturer to mark the entire students at the same time. The application of $i$-learning on blended learning method is not the first time being conducted since many research conduct the same method on different classes. One of them is by Kusumaningsih in her research entitled "Keefektifan Pembelajaran Blended learning Berbasis Kearifan Lokal pada Pembelajaran Matematika”, it was published in Jurnal Pendidikan dan Pembelajaran, Volume 23, Nomor 1 Year 2016. On her research, quasi-experiment pre-test and post-test were applied in which prepared modules were given to the students to be learned and then they had to complete the assignments as presented on LKS (student workbook and assessment). Not only does the hardcopy of the module that was given to the students but also the access to digital materials that were available on website matematikasma.com. The utilization of the modules and website gave a positive impact on student's mark; it created an opportunity to open discussion within the class while the students could still access the material outside the class trough the available website that was prepared by the lectured.

Second, research by Khoiroh (2017) entitled Pengaruh Model Pembelajaran Blended learning dan Motivasi Belajar Terhadap Hasil Belajar Siswa. This research used a quasi experimental method, she found that student motivation who took blended learning classes was higher than students who only got lecture class. In addition, the latest research that correlates to this research was conducted by Fitriasari and friends on Kemandirian Belajar Mahasiswa melalui Blended learning pada Mata Kuliah Metode Numerik. This research also uses a quasi-experimental method for the research, they found out that student who took blended learning class developed learning independence compared to students who only took lecture class.

These three research imply variation in findings although they used the same method in conducting the research. the quasi-experimental method may give positive outcome toward the application of blended learning; however, it may also indicate negative results implying that lecture class mode is much better than blended learning class. As a consequence, this research tries to test out the blended learning method to verify how a blended learning system may influence student motivation in learning the subject.

\section{Methods}

This research is done on university students who take Chukyuu Kaiwa II subject, the students are divided into two different classes A and B, with the entire students who take this subject are around 61 people. Each class will be given 4 quizzes as well as role-play tasks that should be presented in front of the class. Evaluation toward the level of success on the blended 
learning method is seen through final marks that are received by each student. While student's level of satisfaction toward the blended learning method is done trough survey, as the questionnaires regarding student motivation in learning chukyuu kaiwa trough i-learning are spread out.

\section{Result and Discussion}

The application of blended learning on chukyuu kaiwa II subject showed ranges of evaluation in which the marks for Mid Term Test (UTS) are presented as follow;

Table 8. UTS marks trough i-learning

\begin{tabular}{|c|c|c|c|c|c|c|}
\hline Surname & Started on & Completed & Taken Time & $\begin{array}{c}\text { Grade/10. } \\
00\end{array}$ & $\begin{array}{r}\text { Q. } 1 \\
/ \mathbf{0 . 3 3} \\
\end{array}$ & $\begin{array}{c}\text { Q. } 2 \\
/ \mathbf{0 . 3 3} \\
\end{array}$ \\
\hline Afrianti & $\begin{array}{c}3 / 21 / 2019 \\
8: 00\end{array}$ & $\begin{array}{c}3 / 21 / 2019 \\
8: 20\end{array}$ & $\begin{array}{c}20 \text { mins } 3 \\
\text { secs }\end{array}$ & 2.87 & 0.2 & 0.33 \\
\hline Rashif & $\begin{array}{c}3 / 21 / 2019 \\
8: 00\end{array}$ & $\begin{array}{c}3 / 21 / 2019 \\
8: 20\end{array}$ & 20 mins & 6.03 & 0.2 & 0 \\
\hline Novia & $\begin{array}{c}3 / 21 / 2019 \\
8: 00\end{array}$ & $\begin{array}{c}3 / 21 / 2019 \\
8: 20\end{array}$ & $20 \mathrm{mins} 1 \mathrm{sec}$ & 8 & 0.33 & 0.33 \\
\hline IHSAN & $\begin{array}{c}3 / 21 / 2019 \\
8: 00\end{array}$ & $\begin{array}{c}3 / 21 / 2019 \\
8: 19\end{array}$ & $\begin{array}{l}19 \text { mins } 18 \\
\text { secs }\end{array}$ & 8.94 & 0.33 & 0.33 \\
\hline $\begin{array}{l}\text { Khairunni } \\
\text { sa }\end{array}$ & $\begin{array}{c}3 / 21 / 2019 \\
8: 00\end{array}$ & $\begin{array}{c}3 / 21 / 2019 \\
8: 04\end{array}$ & $\begin{array}{c}3 \text { mins } 43 \\
\text { secs }\end{array}$ & 0.67 & - & - \\
\hline Shalwati & $\begin{array}{c}3 / 21 / 2019 \\
8: 00\end{array}$ & $\begin{array}{c}3 / 21 / 2019 \\
8: 20\end{array}$ & $\begin{array}{l}20 \text { mins } 3 \\
\text { secs }\end{array}$ & 3.71 & 0.33 & 0.04 \\
\hline Maulina & $\begin{array}{c}3 / 21 / 2019 \\
8: 00\end{array}$ & $\begin{array}{c}3 / 21 / 2019 \\
8: 21\end{array}$ & $\begin{array}{c}20 \operatorname{mins} 19 \\
\text { secs }\end{array}$ & 6.76 & 0.33 & 0.21 \\
\hline $\begin{array}{l}\text { Nurhasan } \\
\text { ah }\end{array}$ & $\begin{array}{c}3 / 21 / 2019 \\
8: 00\end{array}$ & $\begin{array}{c}3 / 21 / 2019 \\
8: 20\end{array}$ & 20 mins $1 \mathrm{sec}$ & 4.67 & - & 0.33 \\
\hline Fradita & $\begin{array}{c}3 / 21 / 2019 \\
8: 00\end{array}$ & $\begin{array}{c}3 / 21 / 2019 \\
8: 20\end{array}$ & 20 mins $1 \mathrm{sec}$ & 7 & 0.33 & - \\
\hline Lini & $\begin{array}{c}3 / 21 / 2019 \\
8: 01\end{array}$ & $\begin{array}{c}3 / 21 / 2019 \\
8: 20\end{array}$ & $\begin{array}{l}19 \text { mins } 54 \\
\text { secs }\end{array}$ & 7 & 0.33 & - \\
\hline Zulrianti & $\begin{array}{c}3 / 21 / 2019 \\
8: 01\end{array}$ & $\begin{array}{c}3 / 21 / 2019 \\
8: 21\end{array}$ & $20 \mathrm{mins} 1 \mathrm{sec}$ & 5.33 & 0.33 & - \\
\hline Wahyuni & $\begin{array}{c}3 / 21 / 2019 \\
8: 01\end{array}$ & $\begin{array}{c}3 / 21 / 2019 \\
8: 21\end{array}$ & $\begin{array}{c}20 \text { mins } 9 \\
\text { secs }\end{array}$ & 5.96 & 0.33 & 0.29 \\
\hline Agusni & $\begin{array}{c}3 / 21 / 2019 \\
8: 01\end{array}$ & $\begin{array}{c}3 / 21 / 2019 \\
8: 21\end{array}$ & 20 mins $1 \mathrm{sec}$ & 0.07 & 0.07 & 0 \\
\hline $\begin{array}{l}\text { Bless } \\
\text { yuzu }\end{array}$ & $\begin{array}{c}3 / 21 / 2019 \\
8: 01 \\
\end{array}$ & $\begin{array}{c}3 / 21 / 2019 \\
8: 20 \\
\end{array}$ & $\begin{array}{c}18 \text { mins } 56 \\
\text { secs }\end{array}$ & 0.56 & 0.13 & 0.04 \\
\hline \multicolumn{4}{|c|}{ Average } & 6.46 & 0.25 & 0.19 \\
\hline
\end{tabular}

The UTS table explains that the average mark on students is around 64,6 which is equal to B. It indicates that the average mark on students has been increased compares to the previous years which was only 42,6 . The enhancement on student mark may not be significant, but it implied that students have improved their sense of individual responsibility after taking $i$ learning which is not present in a conventional mode of exam. I-learning features in completing the UTS allow the student to improve their sense of responsibility because each student has to complete their own assessment without relying on their friends. As a consequence, students must prepare themselves to be able to answer the question correctly. 
To find the student's opinion regarding the application of $i$-learning, questionnaires that include questions about their opinion on i-learning study are spread out, the findings are shown in the following table:

Table 9: Questionnaire results regarding the application of i-learning on subject chukyuu kaiwa

\begin{tabular}{|c|c|c|c|c|c|c|}
\hline \multirow{2}{*}{ No } & \multirow{2}{*}{ Questions } & \multicolumn{4}{|c|}{ Answers } & \multirow{2}{*}{ Total } \\
\hline & & $\begin{array}{l}\text { Strongly } \\
\text { agree }\end{array}$ & $\begin{array}{l}\text { Somewhat } \\
\text { Agree }\end{array}$ & $\begin{array}{l}\text { Doubt/ } \\
\text { Neutral }\end{array}$ & Disagree & \\
\hline 1 & Can you use i-learning properly & 7 & 19 & 25 & 10 & 61 \\
\hline 2 & $\begin{array}{l}\text { Do you think the application of } \mathrm{i} \text { - } \\
\text { learning method is beneficial in } \\
\text { improving your knowledge }\end{array}$ & 19 & 18 & 17 & 7 & 61 \\
\hline 3 & $\begin{array}{l}\text { Do you enjoy the application of i- } \\
\text { learning method on the subject }\end{array}$ & 12 & 15 & 16 & 18 & 61 \\
\hline 4 & $\begin{array}{l}\text { Do you feel enthusiast in using i- } \\
\text { learning method on the subject }\end{array}$ & 12 & 13 & 21 & 15 & 61 \\
\hline 5 & $\begin{array}{l}\text { Is blended learning better than } \\
\text { the previous learning method }\end{array}$ & 12 & 12 & 22 & 15 & 61 \\
\hline 6 & $\begin{array}{l}\text { Are you pleased with the blended } \\
\text { learning method }\end{array}$ & 8 & 17 & 22 & 14 & 61 \\
\hline 7 & $\begin{array}{l}\text { Do you think the evaluation and } \\
\text { marking process on the blended } \\
\text { learning method is objective }\end{array}$ & 25 & 7 & 19 & 10 & 61 \\
\hline 8 & $\begin{array}{l}\text { Can you master the blended } \\
\text { learning materials }\end{array}$ & 13 & 23 & 17 & 8 & 61 \\
\hline 9 & $\begin{array}{l}\text { Do you think lectured classes are } \\
\text { still needed }\end{array}$ & 61 & 0 & 0 & 0 & 61 \\
\hline 10 & $\begin{array}{l}\text { Does quiz on i-learning help you } \\
\text { in improving your language } \\
\text { capability }\end{array}$ & 19 & 15 & 17 & 10 & 64 \\
\hline 11 & $\begin{array}{l}\text { Should i-learning be } \\
\text { implemented in other sbjects }\end{array}$ & 18 & 16 & 15 & 12 & 61 \\
\hline 12 & $\begin{array}{l}\text { Is blended learning good enough } \\
\text { to be applied on Chukyuu kaiwa } \\
\text { II subject }\end{array}$ & 12 & 20 & 20 & 9 & 61 \\
\hline
\end{tabular}

The table presents questions about students ability in using i-learning, it shows that only 7 students who can use i-learning properly which implies that most of the students are not familiar or unable to use i-learning sufficiently. The answer to the first question also implies an indication that the average mark on the subject does not only come from their capability in mastering Japanese language but also their ability to use i-learning. Although the table shows that fewer students understood the use of i-learning, the second question shows that at least 19 students agree that $i$-learning is beneficial in improving their knowledge; it follows by 18 students who disagree that this method is effectively beneficial in improving their language understanding. This number implies contention as 19 students see the benefit of $i$-learning while the rest 18 believe that it only gives a small portion of the benefit to their studies. The next column shows that 7 students argue that this method gives no benefit at all, and the other 17 students are neutral in taking side whether i-learning gives benefit to their studies or not. 
Further question corresponds to student motivation in using i-learning as presented on questions 3, 4, 5, 6, and 12. The questions evaluate whether the students are excited, enjoy and optimistic in using the $i$-learning system on their subject. The difference in number for each answer is not significant due to a similar tone of those questions, it identifies that 12 students are excited with the application of $i$-learning model on the subject. However, a greater number of students against this assumption (more than 12); in addition, 12 students are in doubt or neutral in expressing their likeness in using i-learning. Besides, 9 students have a bad impression of $i$-learning as these students do not enjoy this model at all.

Question number 9 gives a significant result, it asks whether the face to face class is still needed in which the entire students agree to it. This answer may imply that students do not completely want to leave behind the lecture class model. The answers from other questions on the questionnaire also explain that students are not ready for the implementation of i-learning. Columns for answers "somewhat agree" and "neutral or in doubt" show a significant number that indicates only a few positive answers.

The result of the questionnaire regarding student condition and learning experience with $i$-learning shows a reasonable number. The cause of this case is because it is student first time experience in using i-learning from the website that is provided by Andalas University, although the features for the website is sufficient in improving individual skill. Students must learn to cope with the subject by themselves and they cannot rely on their friends as they used to in their previous classes. The website features that are available at UNAND for each students to study independently and to improve their capability individually. The force that is given by the i-learning method will unconsciously help the students in improving their language skill as shown on the second questionnaire answers correspond to their language capability. Students are confident that their language skill is sufficient as it is presented on the number of answers "very fluent" compare to other available answered.

\section{Conclusion}

It can be concluded that students are still not ready in using i-learning on their university subjects, students may need more times to get familiar with $i$-learning features that are available in website i-learning Andalas University. The unavailable of internet access and technical problems are seen as the major obstacles in the continuity of i-learning system; even though students language capability is proven to be improved compared to the result of the previous method.

\section{References}

[1] Fitriasari Putri, dkk. Januari 2018. Kemandirian Belajar Mahasiswa Melalui Blended learning pada Mata Kuliah Numerik. Jurnal Elemen, Volume 4 Nomor 1, halaman $1-8$.

[2] Khoiroh Ni'matul dkk. September 2017. Pengaruh Model Pembelajran Blended learning dan Motivasi Belajar Terhadap Hasil Belajar Siswa. Jurnal Penelitian Ilmu Pendidikan Volume 10, Nomor 2, Halaman 97 - 110.

[3] Kusumaningsih, Widya, lilik aryanto. April 2016. Keefektifan Pembelajaran Blended learning Berbasis Kearifan Lokal pada Pembelajaran Matematika, Jurnal Pendidikan dan Pembelajaran, Volume 23 Nomor 1 halaman 64-69.

[4] Sudaryanto. 1993. Metode dan AnekaTeknik Analisis Bahasa. Yogyakarta: Wacana University 